\title{
ENTRE CORONAS, CRUCES Y BANDERAS. MONARQUÍA, RELIGIÓN Y NACIONALISMO ESPAÑOL EN LA DICTADURA DE PRIMO DE RIVERA
}

\author{
POR \\ GUILLERMO MARÍA MUÑOZ ${ }^{1}$ \\ Universidad Complutense de Madrid
}

\begin{abstract}
RESUMEN
El estudio trata sobre la Corona española y el catolicismo, analizando el peso de la religión dentro del monarquismo y de la propia monarquía en los sectores católicos, tanto a nivel discursivo como práctico o simbólico. Se destaca especialmente el peso del nacionalismo atendiendo a la conjunción nación-catolicismo desarrollado durante estos años, de ahí la relevancia de la cronología escogida. De la misma forma se aplicará una metodología comparada tanto a nivel temporal (Restauración) como espacial (en un contexto europeo).
\end{abstract}

PALABRAS CLAVE: monarquía; nacionalcatolicismo; imagen pública regia; Alfonso XIII; dictadura.

\section{BETWEEN CROWNS, ROODS AND FLAGS. MONARCHY, RELIGION AND SPANISH NATIONALISM IN THE DICTATORSHIP OF PRIMO DE RIVERA}

\begin{abstract}
The study is about the Spanish Crown and catholicism, analyzing the weight of religion within monarchism and the monarchy itself in the catholic sectors, discursively and practically or symbolically. The weight of nationalism is especially emphasized, considering the nation-catholic conjunction developed for these years, hence the relevance of the chosen chronology. In the same way, a comparative methodology is applied at the temporal level (Restoration) as spatial (in a European context).
\end{abstract}

KEY WORDS: monarchy; nationalcatholicism; royal public image; Alfonso XIII; dictatorship.

Cómo CITAR ESTE ARTículo / CITATION: María Muñoz, Guillermo. 2020. «Entre coronas, cruces y banderas. Monarquía, religión y nacionalismo español en la dictadura de Primo de Rivera». Hispania Sacra LXXII, 146: 579-591. https://doi.org/10.3989/hs.2020.043

Recibido/Received 26-03-2019

Aceptado/Accepted 18-09-2019

\section{INTRODUCCIÓN}

Tanto el catolicismo como la Corona son dos sujetos que no necesariamente, ni en esencia, son nacionales, pero que, sin embargo, han jugado un papel más que destacado en la identidad nacional española desde la construcción del Estadonación durante el siglo XIX. Como señaló Moreno Luzón, «Alabar al rey católico no significaba prescindir de su dimensión nacional, sino reafirmar una manera de ser español». ${ }^{2}$ De esta forma, el estudio de la religión y de la monarquía, y el papel de ambos, en conjunción, en el nacionalismo español

gumaria@ucm.es /

ORCID iD: https://orcid.org/0000-0001-8688-6030

2 Moreno Luzón 2013, 325. de los años veinte darán ciertas claves sobre la relevancia de la Corona en el pensamiento nacionalcatólico durante la dictadura de Primo de Rivera. Es necesario señalar que por las limitaciones espaciales y por la naturaleza del texto estas páginas son una primera toma de contacto con el tema y por tanto una aproximación al mismo.

El aparato teórico-metodológico escogido es el adoptado por las nuevas perspectivas historiográficas dedicadas al estudio de las monarquías, y que han sido tomadas hace relativamente poco en España, existiendo solo estudios de la etapa liberal para el caso de Alfonso XIII. ${ }^{3}$ De hecho, apenas existen trabajos - bajo cualquier perspectiva

\footnotetext{
3 Un estudio más amplio sobre el tema en María Muñoz 2016.
} 
historiográfica - sobre el monarca o la Corona durante la época primorriverista. ${ }^{4}$ Aquellas tendencias se han centrado no tanto en el individualismo metodológico (más propio de la biografía), como en parámetros de la historia del pensamiento político, poniendo en relación la monarquía con las ideologías surgidas durante la época contemporánea. Así, de lo que se trata es de ver la correlación de la Corona con el nacionalismo, cómo se adapta aquella institución a los nuevos tiempos que trajo el liberalismo, constitucionalismo y parlamentarismo, cómo se legitima ante la soberanía nacional y, en definitiva, qué papel efectúa la monarquía en aquellas sociedades contemporáneas donde sobrevivió..$^{5}$ En este nuevo enfoque historiográfico se analiza, por un lado, el contenido político de la Corona y, por otro, cómo se difundió dicha ideología asociada a la monarquía. Así, de lo que se trata es de analizar el simbolismo político de la monarquía, ver las diferentes imágenes públicas regias que se le coligaron y sus diversos modos de socialización. Es lo que se conoce como monarquía escénica. Como si de un teatro se tratase, la Corona encarna una serie de representaciones y funciones - con su contenido político implícito y/o explícito- destinadas al conjunto de la población como público asistente. Mediante una serie de ceremonias y rituales de importante carga simbólica la Corona trata de difundirse entre el máximo de gente posible como un emblema político. ${ }^{6}$ Esta publicitación de la monarquía se llevaría a cabo a través de los viajes regios, las ceremonias nacionalistas, militares, religiosas o civiles. También es necesario tener en cuenta la difusión de la imagen monárquica a través de elementos cotidianos y aparentemente triviales, conformando así, lo que se conoce como «monarquismo banal», término extrapolado del «nacionalismo banal» de Michel Billig. ${ }^{7}$

Por otra parte, también se adoptará una metodología comparada. De una parte, a nivel temporal observando la evolución, los cambios y continuidades entre el periodo liberal y el dictatorial del reinado de Alfonso XIII. Y de otra, a nivel espacial, enmarcándolo en un contexto europeo y cotejándolo con otras monarquías. En lo que respecta a la cuestión religiosa, en algunos aspectos, se tomará una perspectiva culturalista acorde a los nuevos paradigmas de la historiografía de la religión, prestando atención a elementos de la cultura devocional, la espiritualidad o la piedad, siempre en relación con la monarquía. ${ }^{8}$

Antes de entrar en materia es necesario realizar una serie de apuntes con respecto a los otros dos ejes de la investigación: nación y catolicismo. Se apuntaba que la dictadura de Primo de Rivera desarrolló el nacionalcatolicismo como ideología de Estado, una interpretación historiográfica que, a pesar de sus detractores, parece consolidada con el paso de los años. ${ }^{9} \mathrm{Al}$ respecto, ya lo defendió tajantemente Alfonso Botti al decir

\footnotetext{
4 Seco Serrano 1986; Tusell 1993 y 1997, passim; Gómez-Navarro 1991, 101-149 y 2003.

5 El nuevo rol político de la monarquía durante el siglo XIX en Lario 1998

6 Véase, Lario 2017.

7 El concepto de «monarquismo banal» aparece en, Olechnowicz 2007, 33-34; Billig 2014.

8 Montero, de la Cueva y Louzao 2017.

9 La defensa del nacionalcatolicismo de la dictadura primorriverista en Ben-Ami 1983. Recientemente ha sido sustentada por Adagio 2004; Quiroga Fernández de Soto 2008. En contra de dicha interpretación, Tusell 1997.
}

que «con la dictadura de los años veinte se había producido una primera institucionalización del NC [nacionalcatolicismo], que se había convertido en ideología del Estado». ${ }^{10}$

En lo referente a los estudios sobre el catolicismo hay que señalar los progresos historiográficos referidos a ellos. Tradicionalmente se ha contemplado la religión como un elemento antimoderno en el devenir histórico de España, un freno a la modernización del Estado. Así, se ha tendido a ver la historia religiosa de España desde un punto de vista dicotómico al observar el anticlericalismo como la esencia de la modernidad y el catolicismo como su antítesis. ${ }^{11}$ Una visión donde la conjunción nación-catolicismo tenía un papel secundario cuando no inexistente.

No obstante, en lo últimos años nuevas perspectivas han transformado el panorama historiográfico ampliando nuevos temas de investigación. Así, han proliferado los estudios sobre la mujer, el asociacionismo católico, congregaciones religiosas, la educación, la devoción, religiosidad, espiritualidad... Aspectos desarrollados gracias a la adopción de nuevas perspectivas, especialmente la cultural y la de género. ${ }^{12}$ En lo referido a la cuestión de nación-religión, ya a comienzos de los años noventa Botti defendió la relevancia de la religión en el nacionalismo, señalando que el catolicismo, en su variante nacionalcatólica, representaba una modernidad alternativa a la laica y, por tanto, no siendo un elemento antimoderno. La religión se adaptaba a los nuevos tiempos y llegaba a aceptar el capitalismo y el liberalismo económico (que no político). ${ }^{13}$ Empero, esta interpretación fue minoritaria y no volvería a ser defendida hasta recién entrado el siglo XXI, cuando Álvarez Junco recupera la relevancia de la religión en las identidades nacionales, como el propio Botti señaló tiempo después. ${ }^{14}$ Según esta perspectiva historiográfica, ampliamente sustentada, el catolicismo se contempla ahora como elemento indispensable en el nacionalismo, capaz de mover a las masas y que, en definitiva, se adaptaba a la modernidad, recogiendo de ella los elementos que consideraba oportunos para su supervivencia sin llegar a perder su esencia. De esta forma, se complejiza la relación modernidad-catolicismo. Especialmente relevantes han sido los estudios sobre la nación y la religión que han puesto en primera fila el peso del catolicismo en España para el desarrollo de los diferentes tipos de nacionalismo y de los procesos de nacionalización. ${ }^{15}$ En definitiva, se ha enriquecido enormemente el campo de la historia religiosa, hasta el punto de concebir el catolicismo como una serie de culturas políticas diferentes con sus universos y cosmovisiones propias. De esta forma, se puede afirmar que:

La relación entre modernidad y religión no debe por tanto entenderse únicamente desde parámetros funcionalistas. No se trata de una mera adaptación

\footnotetext{
10 Botti 2013, 121.

11 Un ejemplo para el primer tercio del siglo XX en la ya clásica obra Callahan 2003, 19-219.

12 Para ver un estado de la cuestión más amplio remitimos a Hernández Fuertes 2016; Montero, de la Cueva y Louzao 2017.

13 Botti 1992.

14 Álvarez Junco 2001; Botti 2005.

15 Algunas obras que constatan este paradigma historiográfico son: Botti, Montero y Quiroga 2013; de la Cueva Merino 2000; de la Cueva Merino y López Villaverde 2005; Suárez Cortina 2015; Salomón Chéliz 2015; Louzao Villar 2013a y 2015; Ramón Solans 2014 y 2015; Vincent 2013.
} 
de la Iglesia a un contexto moderno, por instinto de supervivencia o como medio para seguir influyendo en la sociedad (lo que algunos autores han conceptualizado como modernidad defensiva o reactiva). La iglesia parece haber contribuido al cambio social también de manera proactiva, desarrollando prácticas innovadoras en distintos ámbitos. ${ }^{16}$

En lo que respecta al catolicismo durante la dictadura primorriverista y a las relaciones entre la Iglesia y el Estado durante esos años existen diversas interpretaciones. Mientras que algunos autores sostienen que la dictadura dio importantes concesiones a la Iglesia, ${ }^{17}$ otros matizan dichas ampliaciones de privilegios, sosteniendo que el Estado siempre tuvo una actitud ambigua hacia la Iglesia, supeditando los intereses eclesiásticos a los del Estado, lo que conllevó una serie de conflictos diplomáticos entre el Vaticano y el Estado español. En cualquier caso, parece un lugar común entre los historiadores que la Iglesia no vio satisfecha todas las demandas que desde hacía décadas llevaban solicitando a los diferentes gobiernos. Ni siquiera la creación de la Junta Delegada del Real Patronato Eclesiástico que ponía bajo control clerical el derecho de presentación de candidatos al obispado satisfizo totalmente al catolicismo, que vio solo esta medida como un primer paso hacia eliminación del regalismo. ${ }^{18}$ Así, se podría decir que el catolicismo español no vio cumplidas las expectativas totalizantes de recatolización de la sociedad española que esperaban de la dictadura, lo que le llevo a su distanciamiento con el régimen contribuyendo a la caída del mismo. ${ }^{19}$ No obstante, como bien señala Botti, la postura del catolicismo frente a la dictadura dependió de los diferentes sectores religiosos. Todos ellos tenían sus esperanzas puestas en el proyecto político primorriverista para la creación de la sociedad cristiana deseada. El fin del régimen y la escasa actividad que desarrolló la Iglesia junto a la dictadura en algunas materias llevaron a calificar, por parte de algunos eclesiásticos, la dictadura como una ocasión perdida para el catolicismo. ${ }^{20}$ Principalmente, los puntos de fricción entre Iglesia y Estado en los años veinte fueron tres: la cuestión educativa y la pretensión monopolizadora del Directorio; la represión estatal al clero catalán ante su supuesto separatismo; y el apartamiento de los sindicatos católicos en las relaciones laborales con el Estado. ${ }^{21}$ Sin embargo, como acertadamente apunta Montero, esto «no implicó una ruptura de la fundamental identificación de valores y colaboración estrecha» entre el régimen primorriverista y la Iglesia. ${ }^{22}$

En lo que respecta a la vinculación entre la monarquía de Alfonso XIII y el catolicismo hay que señalar que este tema es prácticamente inerte en la historiografía, existiendo solo el trabajo de Julio de la Cueva, que trata principalmente dicha relación durante el periodo liberal, apenas entrando en el periodo posterior a $1923 .{ }^{23}$ Por otra parte, también es reseñable el estudio de Cárcel Ortí que trata

16 Ostolaza 2017, 235.

17 Ben-Ami 1983; Martínez Álvarez 2015.

18 Cárcel Ortí 1988, 2010, 2011a y 2011b.

19 Adagio 2004

20 Botti 2004

21 Callahan 2003, 127-139; Quiroga Fernández de Soto 2008 y 2013; Adagio 2004; Perfecto García 1984.

22 Montero 2017, 145.

23 De la Cueva Merino 2003. las relaciones personales de Alfonso XIII con Pío XI. ${ }^{24}$ Para el periodo dictatorial no existe ningún trabajo monográfico sobre el tema, aunque si alusiones secundarias al mismo como, por ejemplo, el estudio sobre la figura del Nuncio Apostólico Tedeschini y sus malas relaciones con Alfonso XIII, a quien culpaba de los perjuicios de los intereses vaticanos en España. ${ }^{25}$ Es curioso que los textos que mejor traten la conexión entre la Corona y el catolicismo durante la dictadura sean los del teólogo Luis Cano en su análisis sobre la devoción al Sagrado Corazón en la España de entreguerras, donde destaca y pone de relieve la importancia de la monarquía en el mundo católico español. ${ }^{26}$

Es necesario entender que durante el periodo de entreguerras se produce un auge del nacionalcatolicismo en toda Europa. Incluso el Vaticano aceptó definitivamente la nación - siempre y cuando fuera católica-, lo que pone de manifiesto la relevancia de la religión como identidad nacional. Si bien el periodo de entreguerras fue la etapa del surgimiento de ideologías consideradas como una autentica religión política - como el fascismo-, también es cierto que el catolicismo tuvo una importancia de primer orden dentro de las ideologías políticas para la sacralización de la política, en el marco de las dictaduras no fascistas. ${ }^{27}$ Así, se entiende mejor la relevancia que llegó a adquirir la Corona alfonsina en el mundo católico.

Aunque, la estrecha relación entre altar y trono no fue algo exclusivo de la monarquía española. Ya desde finales del XIX la colaboración de la Iglesia anglicana con la Corona británica fue crucial en el desarrollo de la escenografía monárquica. Como se demostró con las ceremonias religiosas de los diferentes jubileos - en especial el de diamante- de la reina Victoria. A pesar de que la monarquía inglesa siempre intentó mantenerse como un ente apolítico, estrictamente constitucional y alejado de las disputas partidistas, su conexión con la religión era clara y notoria. Hay que recordar que el soberano británico ostenta el título de cabeza de las respectivas iglesias nacionales - presbiteriana en Escocia y anglicana en Gales e Inglaterra-, y que las coronaciones se efectúan en la abadía de Westminster y son realizadas por el arzobispo de Canterbury. Por no citar la gran preocupación de Victoria en los nombramientos eclesiásticos. ${ }^{28}$ Algo que compartía con Alfonso XIII y sus interferencias en las designaciones cardenalicias y episcopales. ${ }^{29}$ Tampoco hay que olvidar que en la controvertida abdicación de Eduardo VIII la religión tuvo un papel fundamental, pues la Iglesia anglicana no aprobaba la situación matrimonial de la señora Simpson. Mucho menos se podía permitir que el cabeza de una Iglesia que rechazaba el divorcio se casase con una mujer separada. ${ }^{30}$

Gran Bretaña y España no eran los únicos casos. De hecho, era algo habitual que las diferentes monarquías europeas tuvieran una vinculación potente con sus respectivas iglesias, lo que hacía que los soberanos quedasen encarnados como representantes religiosos de las naciones. Así

\footnotetext{
24 Cárcel Ortí 2009.

25 Rodríguez Lago 2017.

26 Cano 2006 y 2007.

27 Botti, Montero y Quiroga 2013.

28 Cannadine 2002; Petrie 1963, 47.

29 Cárcel Ortí 2010 y 2011 b.

30 Petrie 1963, 183, 190 y 191.
} 
ocurrió en la Alemania de Guillermo II y la conexión de este con el protestantismo. Aunque es cierto que el kaiser tuvo una actitud considerada con los católicos a fin de integrarlos en el imperio alemán. En Austria-Hungría, Francisco José era una figura eminentemente católica, donde la religión venía a legitimar la idea supranacional de imperio. De esta forma, el catolicismo servía para atraer lealtades hacia el emperador y evitar los nacionalismos que fragmentarían el Estado. No obstante, hay que señalar una notable diferencia entre los casos citados y el español. Tanto en Gran Bretaña, como en Alemania o Austria-Hungría la representación religiosa de los monarcas fue en cierta medida flexible e inclusiva con respecto a otras confesiones - más teniendo en cuenta el carácter multiconfesional de dichas naciones-. ${ }^{31}$ Algo que no pasó en España, donde Alfonso XIII se erigió como el defensor de lo exclusivamente católico, excluyendo otras confesiones como el islam o el protestantismo, como se podrá comprobar más adelante.

Quizás, en este sentido, la excepción la constituyese Italia, donde la Corona desde la unificación nacional siempre mantuvo una disputa con el Vaticano a raíz de la llamada cuestión romana. Esta confrontación se vio reforzada tras la llegada del fascismo - y la consecuente fascistización de la Corona-, teniendo en cuenta que este se manifestó como una autentica religión política y revolución antropológica sustitutiva del catolicismo y mantuvo serias rivalidades con la Iglesia católica, a pesar de los pactos de Letrán. Así, se podría catalogar a Víctor Manuel III si no como un monarca anticlerical, si muy poco favorable a la Iglesia. De hecho, el soberano italiano llegó a abortar, antes de 1929, en varias ocasiones las negociaciones con el Vaticano para poner fin a la cuestión romana. ${ }^{32}$ Una actitud regia que se volvería a manifestar cuando el rey italiano visitó a Pío XII en 1939 y ni siquiera besó la mano pontificia como mandaba el protocolo en muestra de respeto. ${ }^{33}$

De esta forma, se puede afirmar que la relación entre la monarquía española, la nación y la religión no fue algo excepcional, sino que se inserta dentro de los parámetros europeos - con la excepción italiana-. Aunque, quizá, el caso español tuviera una mayor intensidad que sus correligionarios continentales.

\section{La Corona y la Religión. Algunos antecedentes}

Las conexiones existentes entre la monarquía hispánica y el catolicismo son una constante durante toda la historia. No obstante, con el fin del Antiguo Régimen en España se transfiguran radicalmente estas relaciones. ${ }^{34}$ Tanto Fernando VII, como Isabel II -Alfonso XII en menor medida- destacaron su faceta católica como legitimación del trono, impulsando así la religión como uno de los pilares de la identidad nacional. Si bien es verdad que en 1814 se promovió un discurso religioso que anulaba la soberanía nacional en pos de la providencia divina encarnada en Fernando VII - al estilo de

31 Wolf 2010. La evolución de la actitud de la reina Victoria hacia el catolicismo en Arnstein 1996.

32 Jedin y Repgen 1984, 94 y 95.

33 Colombo 2010, 186. Para una definición de la naturaleza del fascismo italiano véase Gentile 2004.

34 Para el final de la monarquía absoluta, véase La Parra López 2015. las monarquías católicas medievales-, pronto se transformaron los lazos entre el trono y el altar. Lo que perseguía Fernando VII era implantar «un nuevo tipo de monarquía en el que el poder quedaba en manos del monarca sin intermediarios, ni religiosos ni de cualquier otro tipo. Un absolutismo regio de nuevo cuño [...] diferente al del Antiguo Régimen $»{ }^{35}$ Con la instauración definitiva del liberalismo se transforma la concepción de las monarquías de Isabel II y Alfonso XII, que ya no solo se sustentan en su carácter religioso, sino también en el constitucional. El trono mantiene algunas de sus prerrogativas anteriores -especialmente desde 1845 - y sigue estando en el centro del sistema político. No obstante, comparte este espacio con las Cortes, estableciéndose la llamada cosoberanía entre Corona y Parlamento. Una cosoberanía con importantes carencias hasta el punto de poder hablar de una monarquía constitucional y no parlamentaria debido al déficit de parlamentarización del sistema liberal decimonónico español. Así, a pesar de la pérdida de poder que supuso la instauración del liberalismo, la Corona seguía estando en el centro del tablero político. ${ }^{36}$ Se producía así una conjunción entre catolicismo, liberalismo - moderado- y constitucionalismo como pilares fundamentales de la Corona. De hecho, Isabel II tuvo un papel destacado en la reconciliación entre el liberalismo moderado y la Iglesia, plasmado en el Concordato de 1851 y su convenio adicional de 1859. La vinculación y apoyo mutuo entre el catolicismo y la monarca fue algo notable durante todo su reinado, motivado tanto por razones de religiosidad de la reina, como políticas - como la aprobación y legitimación de Isabel II como soberana por parte de la Santa Sede ante las pretensiones carlistas-. Isabel II «no tenía más reglas de orientación política que dos ideas: la defensa de la Iglesia católica y la dignidad de la Corona. A estas dos ideas [...] subordinó toda su actuación». ${ }^{37}$ Así, la reina reafirmó el catolicismo como elemento sustancial de la nación y del trono. Lo que no supuso, ni mucho menos, la tolerancia del liberalismo por una parte importante del clero. $^{38}$

Incluso, el catolicismo estuvo presente en la imagen pública regia de aquellos monarcas no especialmente devotos, como era el caso de Alfonso XII, el cual a pesar de su falta de piedad entendió que no se «podía prescindir [...] del talante católico de sus antepasados, por tradición, pero también por la necesidad de acoger a todos los monárquicos, es decir, también a los carlistas». ${ }^{39}$ Por lo tanto, la religión también serviría como herramienta para atraer a aquellos disidentes del liberalismo y de la rama isabelina. Algo que supone una diferencia sustancial con respecto a los años veinte del siglo XX, puesto que durante la dictadura una parte importante del carlismo se adscribió al régimen primorriverista - y a la Corona, como se verá-. Por lo que no fue necesario el empleo del catolicismo por parte de la monarquía para atraer hacía sí a los tradicionalistas.

Esta presencia de la religión en la imagen pública regia y su vinculación a la monarquía sería continuada durante

\footnotetext{
35 La Parra López 2014, 53. Véase también Alonso 2015.

36 Burdiel 2010; Pérez Garzón 2004.

37 Burdiel 2010, 255.

38 Fernández Sirvent y Gutiérrez Lloret 2014; La Parra López 2004.

39 Lario 2003, 21. Para el reinado de Alfonso XII, véase también Lario 1999.
} 
el periodo de la Restauración (1902-1923) de Alfonso XIII. Esto es constatable, por ejemplo, en algunos acontecimientos monárquicos o en los viajes regios - con la omnipresencia del Te deum en la iglesia de cada destino real,$-^{40} \mathrm{y}$ en las prácticas cortesanas producidas durante dicho reinado. Alfonso XIII a su llegada al trono en 1902 -y durante todo su reinado- renueva o recupera una serie de ceremonias y rituales abandonados durante la regencia de su madre. De esta forma, más que de una «invención de la tradición» al estilo de Hobsbawm, se estaría ante una restauración -con algunas modificaciones- de ceremoniales palaciegos ya existentes. Una serie de ritos cortesanos que estaban estrechamente conectados con el mundo católico, pues, de hecho, el calendario de estas ceremonias se regía por la agenda religiosa. ${ }^{41}$ Un caso similar al austrohúngaro, pues Francisco José también introdujo -en este caso sí se produce una "invención de la tradición»- importantes ceremonias religiosas en la corte, incluso, al igual que en España, también realizaba el Lavatorio de Pies y la procesión del Corpus Christi. ${ }^{42}$

No obstante, como bien ha señalado De la Cueva, Alfonso XIII, por lo menos hasta la Primera Guerra Mundial, intentó que su catolicismo fuese "compatible con buenas dosis de liberalismo" hasta el punto de poder definir al soberano como una mezcla de "católico y liberal». Si bien es verdad que durante la Restauración Alfonso XIII hizo alarde de su título de soberano católico y apoyó los intereses de la Iglesia; también es cierto que en algunos momentos se mantuvo neutral - o, a lo sumo, intentó moderar - con respecto a la política secularizadora de sus gobiernos liberales. ${ }^{43}$ Esto, sin embargo, no debe esconder el hecho de que existieron importantes vinculaciones entre la Corona y el altar durante todo su reinado.

Dos importantes precedentes católico-monárquicos: 1911 y 1919

Antes se apuntaba que el auge de la conjunción monárquico-católica durante los años dictatoriales tuvo una serie de antecedentes en la etapa de la Restauración. En este sentido, y por falta de espacio, se referirá únicamente, y de manera breve, a los dos eventos más importantes de naturaleza católica y monárquica.

El primero de ellos fue el Congreso Eucarístico Internacional de Madrid celebrado en 1911, en un contexto de pleno conflicto entre clericales y anticlericales. El papel de Alfonso XIII en el evento fue bastante destacado, tanto por su patronazgo como por asistir al mismo. De otra parte, el monarquismo del acontecimiento fue bastante potente, fomentado por una serie de símbolos que aludían claramente a la Corona en su conexión con lo católico. ${ }^{44}$

El otro gran evento católico-monárquico fue la consagración de España al Sagrado Corazón de Jesús en el Cerro de los Ángeles en 1919. El culto al Sagrado Corazón representaba el reinado social de Cristo conectado a su vez con la promesa del padre Hoyos en el siglo XVIII. El Sagrado

\footnotetext{
40 Moreno Luzón 2013.

41 González Cuevas 2003; Hernández Barral 2012.

42 Unowsky 1998, 282-283.

43 De la Cueva 2003, 287 y 286.

44 Núñez Bargueño 2017; de la Cueva Merino 2003.
}

Corazón de Jesús encarnaba la pretensión de recatolizar la sociedad y todas las esferas de la realidad, llegándose a convertir en un símbolo del antiliberalismo, del catolicismo social y del nacionalcatolicismo..$^{45} \mathrm{El}$ propio protagonismo de Alfonso XIII -que como encarnación de la nación fue quien consagró España al Sagrado Corazón- sumado a la fecha de realización del acto, el 30 de mayo, día de San Fernando, santo de la monarquía $-\mathrm{y}$ también símbolo antiliberal,$-{ }^{46}$ convirtieron la ceremonia en un acto no solo nacionalcatólico, sino también monárquico. Así, el Sagrado Corazón se transformó en un símbolo político-religioso muy vinculado a la Corona de Alfonso XIII, algo que terminaría de sustentarse durante la dictadura primorriverista. ${ }^{47}$ Siempre existió una relación histórica entre el trono y el altar, empero, la estrecha vinculación del catolicismo con la Corona de Alfonso XIII tuvo su apogeo con la llegada de la dictadura de Primo de Rivera.

LA DICTAdURA DE PRIMO DE RIVERA COMO LUGAR DE ENCUENTRO ENTRE NACIONALCATOLICISMO Y MONARQUÍA

La instauración de un régimen dictatorial de corte nacionalcatólico y militarista, creó, sin duda, un contexto más que favorable para el desarrollo completo y definitivo de la deriva autoritaria que había tomado la Corona desde la Primera Guerra Mundial. ${ }^{48}$ Es decir, la instauración de la dictadura primorriverista consolidó y potenció el nacionalcatolicismo de la monarquía, también defendido por el régimen. En este sentido, hay una total coincidencia en el pensamiento político del Estado y de la Corona, a pesar de las discrepancias personales entre rey y dictador. ${ }^{49}$ Como bien afirmó Adagio, "L'unità fra Chiesa, nazione e Monarchia veniva ribadita in un contesto autoritario legittimato come il più adatto per la difesa deo valori cattolici». ${ }^{50}$

Durante la dictadura, la imagen pública regia - promovida tanto por la propia Corona, como por la Iglesia y el régimen- que se proyectó fue la de un ferviente y devoto católico, que mediante sus actos e iniciativas fomentaba y protegía la religión en España. Para los sectores católicos, el rey había manifestado su piedad católica en numerosas ocasiones lo que le convertía en un protector y garante de la religión, transformándose su catolicismo y patriotismo en la nueva legitimidad de la monarquía a partir de 1923.

Según el nacionalcatolicismo la religión era algo consustancial a España y, por ende, un rasgo imprescindible de todo buen español. Consiguientemente, Alfonso XIII al proclamarse «creyente, como Rey español, demostráis ser Rey de todos los españoles». ${ }^{51}$ Por tanto, se entendía la faceta católica del monarca como el nexo con el resto del pueblo español. Para los sectores católicos «don Alfonso XIII

\footnotetext{
45 Cano 2007.

46 Sobre los usos políticos de Fernando III el Santo, véase Rodríguez López 1991, 587.

47 Un desarrollo más amplio de este evento lo encontramos en las obras ya citadas de Luis Cano y Julio de la Cueva.

48 Moreno Luzón 2003, 15. Para el militarismo del régimen véase Navajas Zubeldía 1991.

49 Las relaciones rey-dictador en Gómez-Navarro 1991, 101-149.

50 Adagio 2004, 93.

51 Regatillo 1927, 16; Real Biblioteca (en adelante RB), II/4091, Homenaje del Instituto de Religiosas Esclavas del Sagrado Corazón de Jesús a S. M. Don Alfonso XIII en el 25 aniversario de su reinado.
} 
era el restaurador del genuino sentido de 'católico'».52 En conexión con esto, se podría decir que los sectores católicos contemplaban la Corona como un salvador espiritual de la patria, al fomentar el mantenimiento de la tradición católica. De este modo, tal y como se manifestó en la catedral de Santander en la misa celebrada por las bodas de plata del rey, en 1927, homenajear al monarca suponía un «deber apremiante de religión y obligado tributo de patriotismo»..$^{53}$

A tenor de lo anteriormente dicho, se puede contemplar la relevancia que tenía la figura regia en el mundo religioso. Alfonso XIII Ilegó a erigirse como un protector de lo católico. A él acudían numerosas órdenes religiosas para que actuase como intermediario ante el Vaticano en la beatificación de sus fundadores, o para pedir consejo o ayuda en diversas cuestiones. ${ }^{54}$ De hecho, el estudio de la correspondencia entre el monarca y diversas órdenes religiosas evidencia no solo el monarquismo de estas, sino la estrecha relación que mantenía la Corona con las asociaciones católicas. ${ }^{55}$ Por ejemplo, en 1928 unas 112 asociaciones católicas diferentes solicitaron al rey la proclamación del día de Cristo Rey como fiesta nacional. ${ }^{56}$

De manera similar pasa con el ingente carteo entre el soberano, los obispos y los cardenales españoles. En abril de 1930 absolutamente todos los prelados españoles manifestaron su adhesión a la monarquía ante los ataques y críticas que había sufrido la Corona en un discurso pronunciado por Sánchez Guerra días antes..$^{57}$ Empero, el monarquismo de la jerarquía eclesiástica española no fue algo puntual sino que se manifestó a lo largo de la toda la dictadura $-y$, en ocasiones, también durante la Restauración-, pues tanto obispos como cardenales mantenían al corriente al monarca de diferentes cuestiones religiosas y políticas, solicitando frecuentemente la ayuda e intervención regia. Por citar solo algunos casos: el obispo de Madrid-Alcalá pidió a Alfonso XIII que intercediese en la constitución de la diócesis como arzobispado, ${ }^{58}$ un asunto espinoso que supuso un duro enfrentamiento entre dicho prelado y el Nuncio Tedeschini. ${ }^{59}$ En junio de 1925 el cardenal Benlloch solicitaba ayuda al rey a causa del conflicto que había surgido entre los Carmelitas Descalzos de San Joaquín enfrentados por una supuesta adscripción al nacionalismo vasco de parte de sus clérigos, la cual llegó a dividir la congregación en dos administraciones diferentes. ${ }^{60}$ En 1924 el obispo de Ciudad Real, Prior de las Órdenes Militares, Narciso de Esténega, solicitaba la intervención regia ante el surgimiento de movimientos protestantes en su diócesis. Algo inadmisible en la nación católica por excelencia. ${ }^{61}$

Incluso la importancia de Alfonso XIII en el mundo católico superó las fronteras españolas llegándose a convertir la figura regia en todo un símbolo religioso transnacional.

\footnotetext{
52 Miróbriga, 15 de mayo 1927.

53 López Arana 1927, 6.

54 Archivo General de Palacio, Reinados, Alfonso XIII (en adelante, AGP, RR, Alfonso XIII), Ca 12428/4 y Ca 12426/9.

55 AGP, RR, Alfonso XIII, Ca 15590/1.

56 AGP, RR, Alfonso XIII, Ca 15978/2.

57 AGP, RR, Alfonso XIII, Ca 15591/1. Este hecho ya lo referenció De la Cueva 2003.

58 AGP, RR, Alfonso XIII, Ca 12425/7.

59 Rodríguez Lago 2012.

60 AGP, RR, Alfonso XIII, Ca 15590/3.

61 AGP, RR, Alfonso XIII, Ca 15590/8.
}

El padre Agustín Galen, presidente del Comité Religioso Ucraniano, pedía ayuda y protección al soberano español en su pretensión de unir la iglesia ortodoxa y católica para frenar el avance del comunismo en Europa del este. De otra parte, en 1926 un obispo venezolano solicitaba la participación de Alfonso XIII - designando un representante regio y enviando una serie de obsequios a los sacerdotes participantes, a lo que accedió el monarca- en la celebración del IV Centenario de la primera misa celebrada en el país. ${ }^{62}$ Dos ejemplos que ilustran el traspaso de fronteras de la imagen de Alfonso XIII como uno de los principales sostenedores y protectores de la religión católica.

\section{El auge de la monarquía católica}

A pesar de que Adagio haya asegurado que no fue hasta el final de la dictadura - tras el rechazo a las pretensiones católicas totalitarias por parte del régimen- cuando la Iglesia optó por el monarca como encarnación del catolicismo y la nación; ${ }^{63}$ lo cierto es que el desarrollo definitivo de la imagen pública nacionalcatólica de Alfonso XIII ya comenzó en 1923. Fue su viaje al Vaticano, en noviembre de 1923, el que despertó un ambiente católico-monárquico sin precedentes hasta el momento. De hecho, este viaje le sirvió a Alfonso XIII como ratificación de su título de "rey católico», terminando de generar una adhesión a la Corona, que había comenzado con la consagración al Sagrado Corazón en 1919, por parte del mundo católico. Con el encuentro con el papa, Alfonso XIII había logrado despertar un auténtico éxtasis católicomonárquico en España. Lo que se manifestó a su regreso a la península y el recibimiento que se le hizo en aquellas ciudades por donde pasó. El diario El Debate lo resumía perfectamente: «el viaje de nuestros Reyes, al mismo tiempo que ha elevado el prestigio de nuestra Patria en el mundo [...] ha tenido también la virtud de tonificar el alma nacional y de vigorizar la fe en nuestros destinos históricos» ${ }^{64}$

La visita regia a Pío XI fue una ceremonia minuciosamente organizada en la cual Alfonso XIII mostró un interés excepcional. De hecho, solicitó al Vaticano el cambio de protocolo transformando lo que debía ser una audiencia casi privada en un solemne acto público donde el soberano mostraría su fidelidad al sumo pontífice ante todo el Sacro Colegio Cardenalicio. Una petición que impresionó al mismo Pío XI. En otras palabras, el monarca español convirtió la ceremonia habitual en un rito fastuoso de devoción católica al papa en nombre de la nación española. Tras varias genuflexiones y tras besar los pies del pontífice, Alfonso XIII leyó un discurso historicista nacionalcatólico donde referenciaba las grandes gestas católicas nacionales remarcando así la religión como esencia y grandeza de España. Hasta tal punto se reafirmó el carácter católico de la nación que Alfonso XIII erigió a España como la mayor defensora de la religión y del Vaticano, tal y como lo había hecho durante su historia - ante los protestantes y musulmanes-, estableciendo así un hilo conductor con el pasado patrio. Incluso, el soberano español se autoproclamó representante de

62 El caso ucraniano en AGP, RR, Alfonso XIII, Cạ 15981/4, y el venezolano en Ca $15591 / 1$.

63 Adagio 2004, 253.

64 El Debate, 28 de noviembre de 1923. Sobre el regreso de Alfonso XIII a España, véase Soldevilla 1924, 441-446. 
las naciones hispanoamericanas solicitando para ellas una mayor representación en el Sacro Colegio Cardenalicio. Más allá de la escenografía de esta ceremonia, en la audiencia privada entre soberano y papa, este expuso a Alfonso XIII las cuestiones que más le preocupaban. Así, el acontecimiento también sirvió para exponer los ejes de la política exterior que ambos Estados tendrían con respecto hacía el otro. ${ }^{65}$

Ciertamente, la relevancia de este acontecimiento fue de primer orden. Como acertadamente apunta Cano, «El entusiasmo patriótico-religioso-monárquico se desbordó. La figura del Rey salió transfigurada de ese viaje». ${ }^{66} \mathrm{De}$ hecho, la relevancia de la visita regia al pontífice también puede contemplarse en el hecho de que esta sirvió de acto de reconciliación de parte del tradicionalismo con la dinastía Borbón al publicar El Siglo Futuro el discurso del rey y la contestación del papa. Edición que entregó personalmente Manuel Senante, director del citado periódico carlista, a Alfonso XIII. Como señala Eugenio Vegas Latapié en sus memorias, esto constituyó «un gesto de público reconocimiento de la dinastía liberal por el grupo integrista». ${ }^{67}$

La exaltación católico-monárquica fue tal que la jerarquía eclesiástica estableció, a los pocos días del regreso del rey, que se leyera el discurso regio ante Pío XI en todas las iglesias de España. ${ }^{68}$ El uso político de la visita regia a Pío $\mathrm{XI}$ para el fomento de la corriente monárquico-católica se prolongó, al menos, hasta el año 1925, cuando el ferviente propagandista alfonsino Benigno Varela - con motivo del año santo- publicó un extenso libro -en español e italiano- sobre aquel viaje, incluyendo mensajes de prelados de todo el mundo que alababan el catolicismo de Alfonso XIII. ${ }^{69}$ Como reflujo de aquel acontecimiento, en la conferencia de metropolitanos celebrada el 12 de diciembre de 1923 se instauró el 30 de mayo como "Fiesta Nacional», rememorando la consagración al Sagrado Corazón realizada por el monarca. También se estipuló que se leyera en cada parroquia española la misma fórmula que había recitado el soberano, incluyendo, en ocasiones, alguna modificación con elogios y bendiciones a la familia real. ${ }^{70}$ Incluso se proyectó la realización de un monumento a Alfonso XIII en el mismo Cerro de los Ángeles, lugar de peregrinación cada 30 de mayo. ${ }^{71}$ Sin ninguna duda, durante la dictadura de Primo de Rivera la figura regia había terminado de asociarse a un símbolo religioso de fuerte carga política y con evidentes connotaciones antiliberales y nacionalcatólicas, como lo era la devoción al Sagrado Corazón.

No obstante, esta conexión entre la Corona y la religión tuvo más manifestaciones más allá del culto al Sagrado Corazón. Durante toda la dictadura primorriverista la unión entre el trono y el altar se puso de manifiesto en numerosos eventos y ceremonias donde lo católico y lo monárquico, en conjunción con lo nacional, se unían y tenían un papel fundamental.

65 Cárcel Ortí 2009. El discurso de Alfonso XIII en Gutiérrez-Ravé 1955, 248-252.

66 Cano 2006, 187 y 2007.

67 Vegas Latapié 1983, 24.

68 Rubio Cabeza 1986, 115.

69 Varela 1925.

70 Actas de las conferencias de metropolitanos españoles (19211965), edición a cargo de V. Cárcel Ortí. 1994. Madrid: Biblioteca de Autores Cristianos: 174, 175 y 184.

71 Botti 2004, 82-83.
La Corona omnipresente en lo católico y lo católico omnipresente en lo monárquico

La dictadura de Primo de Rivera fue proclive a la celebración de numerosos fastos y ceremonias nacionales donde la religión católica tenía un importante papel simbólico, además de producirse también importantes eventos eclesiásticos que ponían de manifiesto la importancia del catolicismo en la ideología del régimen..$^{72}$ En muchos de esos ritos la figura de la monarquía como símbolo nacional tuvo una presencia primordial.

El 12 de octubre de 1928 Alfonso XIII, junto con el cardenal Segura, Primado de España, presidió uno de los actos más importantes del catolicismo español de los años veinte: la coronación de la virgen de Guadalupe como «Reina de la Hispanidad».

El acontecimiento fue extraordinariamente publicitado en todo el país y exhibido como un gran acto católico al nivel que lo había sido la consagración de España al Sagrado Corazón en 1919 - como de hecho arengó el propio Primado cuando recibió la corona de manos del rey en la misma ceremonia-. La elección de la virgen de Guadalupe para ser coronada se debió a varios motivos. En primer lugar, a razones hispanoamericanas a tenor del enorme culto que recibía esta virgen en México, país que por aquellos años además se hallaba enfrascado en las guerras cristeras. Así, el acto de la coronación pretendía estrechar vínculos espirituales con el continente americano mediante la religión, además de crear lazos afectivos hacia los católicos de aquel país. En segundo lugar, hay una motivación personal del propio Pedro Segura - verdadero organizador de la coronación y muy vinculado a Alfonso XIII-, pues cuando fue obispo de Coria, diócesis a la que pertenecía el monasterio de Guadalupe, solicitó al Primado de entonces la coronación canónica de la virgen. ${ }^{73}$

El evento fue celebrado en el mismo monasterio de Guadalupe con numeroso público -más teniendo en cuenta la localización y tamaño del pueblo homónimoy minuciosamente organizado. Las calles del municipio estaban engalanadas con banderas nacionales y arcos de ramaje, se organizaron durante toda la semana actos de diverso tipo (aunque, sobre todo, religiosos, como la celebración de unas 2.000 misas y 25.0000 comuniones), se dio un permiso especial a los soldados naturales de Guadalupe para que asistieran al acto, se contrataron varios aeroplanos que lanzaron flores desde el cielo durante la procesión de la virgen tras su coronación y se acuñaron una serie de medallas conmemorativas. La ceremonia contó con la presencia de un batallón militar, con numerosas representaciones eclesiásticas (el Nuncio Apostólico, prelados y diferentes corporaciones de órdenes religiosas), de la nobleza y de algunas diputaciones provinciales, además de la presencia de los ministros de Instrucción Pública y de Gracia y Justicia. De esta manera, se pretendía transmitir la idea de que España entera estaba representada corporativamente en la ceremonia, suponiendo así un episodio de culto de toda la nación hacia la virgen, ejecutado a través del monarca, como personificación de la patria.

\footnotetext{
72 Quiroga Fernández de Soto 2008.

73 Molina y Nieto 1928, 24-27 (en RB, VIII/9162)
} 
La ceremonia y los actos anejos contaron con una gran cantidad de elementos monárquicos, tanto simbólicos como discursivos. Por ejemplo, se vistió a la virgen con el manto que le regaló la infanta Isabel Clara Eugenia, gobernadora de los Países Bajos en el siglo XVII, «en atención a la procedencia regia de la ofrenda». ${ }^{74} \mathrm{O}$ como el bastón de mando que ofreció el monarca a la propia virgen. El día 11 se celebró en el municipio de Guadalupe un certamen literario en honor de Alfonso XIII donde se leyeron diversos poemas y discursos dedicados al rey. Entre ellos destaca la alocución del padre Villacampa titulada: "Alfonso XI, 'el del Salado', Alfonso XII, 'el Pacificador' y Alfonso XIII, 'el Católico': relaciones de estos gloriosísimos monarcas españoles con el Santuario». En este discurso se exaltaba la faceta católica del soberano al mismo tiempo que se lo presentaba como «la representación genuina de la Patria» realizando el acto también «en nombre de la América Española, porque sois la encarnación viva de la Historia», pues Alfonso XIII era el "heredero de las virtudes de Fernando e Isabel de Castilla». Terminaba el discurso diciendo: "Honor y bendición al Rey bueno, al Rey Católico, al Rey más español de todos los Reyes de España». ${ }^{75}$

La imagen pública regia que se quiso transmitir con esta ceremonia fue eminentemente católica y nacionalista $y$, en un segundo plano, hispanoamericana. ${ }^{76} \mathrm{Al}$ igual que en 1919 en el Cerro de los Ángeles, Alfonso XIII como rey católico personificaba y representaba a España homenajeando con todos los honores a una virgen que tenía fuertes vinculaciones con Hispanoamérica - no solo por su culto en México, sino también por ser una virgen ante la que se habían postrado numerosos conquistadores españoles-. De esta manera, Alfonso XIII reafirmaba otra vez su título de "rey católico» y pasaba a encarnar, una vez más, la España católica. Su religiosidad le servía para identificarse con su pueblo. De hecho, como proclamó Segura justo antes de coronar a la virgen, el monarca era «hijo de la Virgen de Guadalupe», ${ }^{77}$ pues como había señalado el día anterior en un discurso, Alfonso XIII tenía una vinculación especial con esta virgen, ya que cuando era niño y estaba gravemente enfermo su madre María Cristina se encomendó a ella para que sanase. Mediante este catolicismo el soberano pasaba a transformarse en el «heredero de las más altas cualidades de sus antepasados, el que de todos los Alfonsos puede ostentar los títulos más preclaros: Alfonso XIII, el bravo, el noble, el batallador, el arrogante, el católico». ${ }^{78}$ En definitiva, en el mejor rey de España, todo ello gracias a su catolicidad.

El nacionalismo del evento y de la imagen pública de la monarquía quedaba retratado no solo en la fecha de celebración, 12 de octubre, fiesta nacional, sino también en la lectura nacionalcatólica y providencialista que se hizo de la ceremonia y de la virgen de Guadalupe. Algo normal si se tiene en cuenta que desde mediados del siglo XIX la piedad mariana se fue desarrollando en estrecha conjunción con el

\footnotetext{
74 «El vestido que ostentará la Virgen», $A B C, 12$ de octubre de1928, p. 15

75 Villacampa 1928.

76 También, a una escala muy inferior, se promocionó una imagen regia asociada al regionalismo extremeño, presentando a Alfonso XIII como el "rey de las Hurdes» a raíz de su famoso viaje, impulsor ahora del culto nacional a Guadalupe.

77 Crónica de la coronación de la Virgen de Guadalupe, Cáceres, 1928, 60 (RB ARM29/1833).

78 Molina y Nieto 1928, XIV-XV.
}

nacionalismo español. ${ }^{79}$ En 1928, el mundo católico vinculó la imagen de la virgen a la misma historia nacional, argumentando que el comienzo del culto a Guadalupe empezó con la Reconquista y su auge fue paralelo al esplendor imperial de España, por lo que el acto de la coronación de la virgen supondría el resurgimiento de la gloria nacional. ${ }^{80} \mathrm{Y}$ es que España era un pueblo providencial favorecido por Dios, como demostraba la historia patria y su vinculación al culto mariano de Guadalupe. Un autor de la época lo resumía de la siguiente manera:

A medida que el templo maravilloso de Guadalupe surgía, levantábase también augusto y magnifico el edificio de la unidad política de España, y cuando ambos estuvieron coronados, el culto de esta Imagen y el prestigio de esta nación rebasaron los mares y las fronteras [...] Esto es lo que sucedió entonces y esto es lo que es de esperar que suceda ahora. ${ }^{81}$

De esta forma, Alfonso XIII a través de la coronación de la virgen de Guadalupe lograría restaurar la grandeza nacional, ya no solo regenerar España, sino lograr que la patria regresase a su máximo esplendor y apogeo imperial. Como se dijo entonces, «Dos hechos con íntimo enlace, derivación el uno del otro: el de la aparición de Santa María de Guadalupe en los años de Alfonso XI de Castilla y su coronación en los días de Alfonso XIII de España, sobrados son para demostrar esto palmariamente». ${ }^{82}$ Así, este providencialismo nacionalcatólico quedaba inexcusablemente ligado a la monarquía española y se fijaba el trono como un símbolo consubstancial dentro del universo nacionalista católico. En otras palabras, sin monarquía era impensable la mediación divina para la grandeza patria. Lo que sin duda colocaba a Alfonso XIII y a la monarquía en un lugar preeminente dentro de la simbología nacionalcatólica. Una imagen de la monarquía muy similar - si no igual- a la que tenía el cardenal Segura, que fue quien organizó la ceremonia. ${ }^{83}$ Lo que denota una pretensión deliberada y organizada de fomentar esta faceta concreta de Alfonso XIII. Este no fue el único caso donde una devoción católica estaba estrechamente vinculada a la historia nacional y a la monarquía. Algo similar ocurrió en los años de entreguerras con la familia real húngara exiliada en Lekeitio, el Cristo de Limpias y su conexión con la historia más reciente de la Hungría de entonces. ${ }^{84}$

La virgen de Guadalupe pasó a encarnar la «esperanza de la reconstrucción de España», gracias a la cual el pueblo español presenciará «el glorioso resurgir de nuestra grandeza milenaria». ${ }^{85}$ Como señaló el propio cardenal Segura, Guadalupe pasará a ser «el templo expiatorio de los delitos nacionales». ${ }^{86}$ En un sermón, días antes de la ceremonia,

\footnotetext{
79 Louzao Villar 2013b.
}

80 Para lo relativo a la coronación de la virgen de Guadalupe, se han consultado las siguientes fuentes: $A B C, 12$ y 13 de octubre de 1928; Nuevo Día. Diario de la provincia de Cáceres, 12 y 13 de octubre de 1928; Extremadura. Diario regional de acción católica, 12 de octubre de 1928; Crónica de la coronación de la Virgen de Guadalupe; Molina y Nieto 1928; El Siglo futuro, 12 y 13 de octubre de 1928.

81 Molina y Nieto 1928, XIV.

82 Ibídem, XII.

83 Martínez Sánchez y Dionisio Vivas 2013

84 Christian y Krasnai 2002-2003.

85 Crónica de la coronación de la Virgen de Guadalupe 1928, 28.

86 Ibídem, 32. 
predicado también por Segura, afirmó que la «Virgen librará a España de la impiedad moderna», siendo España «el pueblo escogido por Dios para la realización de trascendentales destinos $"{ }^{87}$ Este providencialismo no era mera retórica, sino que formaba parte del sistema de creencias del universo católico -o, por lo menos, de una parte-, generando una intensa emocionalidad. Tal fue esta que incluso se llegó a un estado de excitación y frenesí entre los asistentes (como manifiestan las crónicas de la prensa), otorgando a la ceremonia una suerte de aura místico-religiosa, de milagrería. Como expuso el diario $A B C$, en el momento en que la corona quedó depositada en la cabeza de la virgen, «La joya, herida por los rayos del sol, despedía magníficos fulgores $»{ }^{88}$ de tal manera que se formó un «halo inmenso, lúcido, trasparente, que al nimbar la imagen sacrosanta, parece coronar a España entera", todo ello al son de la Marcha real que no hacía sino solemnizar aún más la escena. ${ }^{89}$ En el momento en que el rey otorgó al cardenal Segura el bastón de mando para que lo depositara a los pies de la virgen, el público arrancó en «lágrimas y vítores», logrando un estado de conmoción que afectó también al mismo monarca. El ministro de Gracia y Justicia definió la ceremonia como una «verdadera apoteosis». ${ }^{90}$ Incluso, se llegó a decir que la buena meteorología de aquel 12 de octubre - ante los nubarrones de los días anteriores - se debió a la intervención divina como una muestra de la gracia de Dios para con España. ${ }^{91}$ Una gracia y una providencia divina en favor de España en la cual Alfonso XIII tenía un papel fundamental. Lo que reafirmaba así su imagen como símbolo católico necesario de la prosperidad y gloria nacional.

Por otra parte, en los años de la dictadura se produjeron una serie de congresos católicos de gran relevancia para la Iglesia en los cuales los elementos monárquicos vuelven a aparecer. ${ }^{92}$ La apertura del Congreso Nacional de Educación Católica de 1924 -durante el cual también se realizó una peregrinación al Cerro de los Ángeles- celebrado en el Teatro Real estuvo presidido por Alfonso XIII. Además, en el telegrama enviado al papa se hacía referencia a la «augusta presencia nuestro Rey católico" que solemnizaba el acto..$^{93}$ La sesión de clausura de este mismo congreso - presidida por la infanta Isabel- trató sobre la mujer en su función como educadora e introductora del espíritu nacional y la fe católica en las nuevas generaciones de españoles. El obispo de Madrid-Alcalá aludió a la reina María Cristina como "modelo de madres educadoras» ante la excelente labor que había realizado con su hijo Alfonso XIII. ${ }^{94}$ Pero, ni siquiera era necesaria la presencia regia para que el monarquismo estuviera presente en los actos eclesiásticos. Así se evidenció en el III Congreso Eucarístico Nacional de 1926 celebrado en Toledo con la asistencia de algunos ministros pero no del rey. A pesar de ello, el Primado de España envío un telegrama a Alfonso XIII que decía: «Nuestro testimonio

\section{Ibídem, 36}

88 "El acto solemne de la coronación», $A B C, 13$ de octubre de 1928, p. 15.

89 Molina y Nieto 1928, 225.

90 Ibídem 224 y 228.

91 Ibídem X-XI.

92 Montero 2017, 141-170.

$93 \quad A B C, 22$ de abril de 1924.

$94 \quad A B C, 27$ de abril de 1924. fidelidad adhesión respetuoso afecto; ofreciendo rogar fervientemente estos días por las necesidades e intenciones augusta persona Vuestra Majestad $» .{ }^{95}$ También, durante el Congreso Nacional de la Acción Católica celebrado en 1929, a pesar de que el monarca tampoco asistió, hubo palabras de exaltación de la faceta católica de Alfonso XIII al decir el Nuncio Apostólico que era "el primer católico español, siempre dispuesto a verter su sangre por Cristo, por el Papa y por España». ${ }^{96}$

La defensa católica de la monarquía era constante e incluso se adelantaba en muchas ocasiones a las iniciativas estatales. Así ocurrió con el homenaje especial realizado a Alfonso XIII el 23 de enero de 1925. A mediados de diciembre del año anterior la Junta de Acción Católica propuso efectuar un gran acto de adhesión monárquica, recogiendo después el testigo el régimen, quien acabaría organizando el homenaje. ${ }^{97}$ Durante las bodas de Plata de Alfonso XIII, una celebración eminentemente monárquica y nacional, en todas las parroquias de las diferentes diócesis se celebró una misa en honor al monarca bajo mandato de los obispos, estableciéndose en muchos lugares que se realizase un discurso monárquico en el sermón de la misma. ${ }^{98}$ Algo que era habitual en el resto de dinastías europeas, como pusieron de manifiesto las celebraciones religiosas efectuadas durante los diferentes jubileos de la reina Victoria o de Francisco José, donde, además, la Iglesia católica realizó un importante discurso legitimista a favor del emperador. ${ }^{99}$

Por otra parte, en los numerosos viajes del monarca por la península también eran constantes los elementos católicos, ya fuera con la celebración de un Te deum en cada ciudad que visitaba, inaugurando edificios católicos, cuando no visitaba directamente importantes santuarios, como el de Loyola en 1926, ${ }^{100}$ o el de Lluch en $1930 .{ }^{101}$ No obstante, en este sentido, hay que señalar que Alfonso XIII no hizo sino continuar con una práctica que llevaba realizando desde comienzos de su reinado. ${ }^{102}$

Fue con la visita regia al monasterio de Montserrat a finales de mayo de 1929 cuando se produjo otra importante ceremonia nacionalcatólica y monárquica. Alfonso XIII, aprovechando su viaje a Barcelona con motivo de la inauguración de la Exposición Internacional, acudió el 28 de mayo al monasterio de Montserrat - de clara tendencia catalanista - con motivo de la celebración de un importante evento. Este consistió, a grandes rasgos, en el ofrecimiento de una bandera de España - costeada por todas las diputaciones españolas, cuyos presidentes estuvieron en la jornada - por parte del rey a la virgen de Montserrat. Otra vez al igual que en 1919 y en 1928, el monarca quedaba representado como personificación y mediador de la nación por la cual volvía a mostrar la catolicidad de España. Al ofrecer la insignia nacional a un símbolo católico, pero también catalanista, dio al rito un fuerte carácter españolista.

\footnotetext{
95 El Siglo Futuro, 22 de octubre de 1926.

$96 \quad A B C$ (Sevilla), 19 de noviembre de 1929.

97 Cano 2007, 337.

99 Peters 1998; Cannadine 2002; Unowsky 1998.

100 La Hormiga de oro, 30 de septiembre de 1926.

101 Los Santuarios católicos, 15, 1930.

102 Moreno Luzón 2013; Barral Martínez 2016.
}

98 Algunos ejemplos en, Boletín Oficial del obispado de Tenerife, 1 de mayo de 1927 o Boletín Oficial del obispado de Menorca, 6 de abril de 1927. 
En la oración que leyó a la virgen, Alfonso XIII realizó un discurso nacionalista español de afirmación de la unidad patria y religiosa al decir que «todos los españoles queremos que España sea una, santa y católica [...] Así, nos uniremos todos en el amor a la patria y a la religión». ${ }^{103}$ El rey también introdujo un elemento eminentemente monárquico al ofrecer a la imagen sagrada el manto de su recién difunta madre María Cristina. La presencia de los presidentes de las diputaciones provinciales se interpretaba como una muestra de la unidad nacional pues, en palabras de Primo de Rivera, supuso la «unión de todas las provincias españolas por la voluntad de ellas mismas, impulsadas por verdadero, espiritual y desinteresado patriotismo». ${ }^{104}$ En esta ceremonia del monasterio de Montserrat se encuentran una serie de símbolos católicos (la virgen), monárquicos (el protagonismo regio y el manto de María Cristina) y nacionales (la bandera española costeada por todas las diputaciones y la presencia de sus presidentes) conformando así un conglomerado que representaría la concepción de nación defendida por la Corona y la dictadura de Primo de Rivera. Tal y como expuso el periódico oficioso de la dictadura, La Nación, el acto supuso «la consagración solemne de tres principios fundamentales que hoy sirven de lema a una creciente y vigorosa organización ciudadana: Patria, Religión y Monarquía». ${ }^{105}$ Lo que manifestaba la naturaleza de la nación que defendía el régimen, donde la monarquía y la religión eran consustanciales a la patria. Otra vez más, con la mediación de Alfonso XIII como encarnación de la nación, España se definía como católica y monárquica expresada mediante una serie de símbolos ofrecidos a la virgen de Montserrat.

\section{¿ «La adoración religiosa de la figura regia»? ?106}

Durante los años veinte se asiste a una suerte de identificación de Alfonso XIII como representante religioso de la nación. Algo que se podría situar a medio camino entre la santidad y la normalidad. Gran parte de los sectores católicos contemplaban al monarca como un representante de Dios en la sociedad civil, por lo que rendirle homenaje «es lo mismo en último término que rendírselo a Dios», puesto que toda autoridad venía emanada del Altísimo. ${ }^{107}$ Este discurso católico tenía, en ocasiones, una concepción divina de la monarquía, al decir que Alfonso XIII es "Ante todo un representante de Dios», por lo que tenía "la asistencia divina». ${ }^{108}$ Incluso se situaba a los soberanos por encima del resto de seres humanos, de los cuales se decía que si tenían un ángel de la guarda un monarca tenía dos. En el caso de Alfonso XIII esta sacralidad se manifestaba en la protección divina que recibía y que le había permitido sobrevivir a los múltiples intentos de regicidio. ${ }^{109}$ La causa de la asistencia divina y de la superioridad del monarca con respecto al resto de mortales debía de encontrarse en su piadosa religiosidad y defensa de la España católica.

\section{Gutiérrez-Ravé 1955, 310.}

104 "La importancia de los actos de ayer», La Nación, 29 de mayo de 1929 , p. 5.

105 «El solemne acto de ayer en la montaña de Montserrat», ibídem, p. 1.

106 Este concepto se ha tomado del trabajo de Wolf 2010.

107 López Arana 1927, 14-15.

108 «El Rey en los Clásicos», El Debate, 17 de mayo de 1927.

109 Regatillo 1927, 20.
De esta manera, no es extraño que, en fecha desconocida, se llegase a emparentar a Alfonso XIII con Santo Domingo de Guzmán, lo que sin duda contribuía a la adoración religiosa del rey. ${ }^{110}$ De otra parte, hay que entender que el papa como representante religioso de Dios es una figura sagrada para el universo católico, ${ }^{111}$ y que, por tanto, Alfonso XIII al ser el representante civil de Dios se movería en aquellos límites de la sacralidad. De hecho, monarca y Sumo Pontífice no eran figuras tan alejadas entre sí. En 1929 - con el fin de costear las excavaciones de las catacumbas del Vaticano- se emitieron una serie de sellos únicamente vendidos en Toledo, como sede del Primado de España y en Santiago de Compostela, sede del patrón de España- donde aparecían las efigies de Alfonso XIII y de Pío XI, bajo la leyenda "Pro fide et artibus». ${ }^{112}$ Así, es como aparecían representadas las, quizás, dos figuras más importantes del catolicismo en España, su representante civil y religioso respectivamente. Tal vez, pueda parecer exagerado hablar de una adoración religiosa de Alfonso XIII, aunque este concepto ya se ha aplicado a otros monarcas. ${ }^{113}$ No obstante, lo que sí parece claro es que en los años veinte se produce una adulación hiperbólica de su faceta católica por parte de no pocos integristas.

\section{CONCLUSIONES}

A lo largo del texto se ha visto cómo la relación entre la monarquía y el catolicismo fue profundamente estrecha hasta el punto de concebirse la Corona como la mayor garantía de la religión y de la instauración de una España verdadera y totalmente católica. El proyecto de recatolización de la sociedad tuvo como uno de sus emblemas a la Corona alfonsina. Solo mediante el establecimiento de una monarquía auténticamente católica, como lo era la que arrogaba Alfonso XIII, el catolicismo lograría sus aspiraciones totalizantes. ${ }^{114}$

Precisamente, este impulso de la imagen pública regia católica fue favorecido por el contexto dictatorial y por las propias actuaciones de Alfonso XIII como la visita al papa, la coronación de la virgen de Guadalupe o el acto de Montserrat. Acciones regias gracias a las cuales el soberano era contemplado por el mundo católico como un guardián y defensor de la tradición religiosa española. En este sentido, el catolicismo y la Corona se retroalimentaban. La monarquía se proclamó defensora de la religión y la Iglesia potenció más que nunca su monarquismo. Al mismo tiempo, este discurso otorgaba a la monarquía una nueva legitimidad - la exclusivamente católica y ajena al constitucionalismo- que no había tenido precedentes hasta el momento. Una legitimidad católica que superaba la teoría del Antiguo Régimen del origen divino de la monarquía como justificación de la misma. ${ }^{115} \mathrm{El}$ mantenimiento del trono en España durante la dictadura se basaba en el hecho de que la Corona era la garantía de la salvaguarda de

110 AGP, RR, Alfonso XIII, Ca 12811/19.

111 La devoción católica al papa aparece reseñada en Louzao 2015, 463.

112 La lectura dominical, 28 y 29 diciembre de 1928; La hormiga de oro, 17 de enero de 1929. El permiso de emisión de dichos sellos en Gaceta de Madrid, 15 de julio de 1928, Real Orden Circular 1.478.

113 Wolf 2010

114 Estas afirmaciones ya han sido defendidas Cano 2007, 477.

115 La Parra López 2015. 
una religión que a su vez era la esencia de la nación y sin la cual esta no se podía entender. Es decir, indirectamente la Corona se transformó en un pilar fundamental de la nación, pues avalaba el mantenimiento del catolicismo y este a su vez hacía lo propio con la nación. De esta manera, se habría «monarquizado la nación», ${ }^{116}$ pues el trono se había transformado en algo consustancial y necesario para la España católica, convirtiéndose también en un símbolo esencial del nacionalcatolicismo de los años veinte. Como aseveraba uno de los principales ideólogos primorriveristas, José María Pemán, en una de sus obras más importantes: «Afirmar la Patria, en España, es afirmar conjuntamente la Religión y la Monarquía [...] Estas son, en efecto, las dos máximas realidades españolas», ya que "la tradición nos muestra la Monarquía como elemento sustancial y formativo de la nación». ${ }^{117}$ Así, más que de una legitimidad católica de la monarquía, quizá habría que hablar de una legitimidad nacionalcatólica, puesto que el elemento nacional era factor indispensable en el mantenimiento del trono.

Es cierto que las relaciones entre el trono y el altar fueron algo constante durante el siglo XIX y comienzos del XX. Por lo tanto, lo analizado a lo largo de estas páginas no resultaría, en apariencia, algo nuevo. Quizá, lo que sí resulte novedoso sea la intensidad con que se produjo la exaltación de la faceta católica del rey y la relación existente entre la religión y la Corona. El fenómeno en sí no era algo innovador dentro de la monarquía española, pero sí el grado de exaltación y la magnitud con la que se produjo. Durante la dictadura de Primo de Rivera, la Corona al perder gran parte de su legitimidad con la suspensión de la Constitución, volcó su legitimidad en el aspecto católico como una suerte de rey providencial, representante civil de Dios que garantizaba el orden y el progreso patrio sin que la nación perdiera su médula, el catolicismo. Por lo tanto, se puede apreciar un punto de ruptura con respecto al periodo anterior, la Restauración, donde el liberalismo tenía presencia. Algo semejante, salvando las distancias, a lo efectuado por Fernando VII que también basó su legitimidad en 1814 en el aspecto religioso al suspender la Constitución de Cádiz. ${ }^{118}$

En definitiva, como se ha podido observar a lo largo del texto, la figura de Alfonso XIII aparece estrechamente unida a los principales cultos del universo católico, como lo eran la devoción mariana -en 1928 a través de la virgen de Guadalupe y en 1929 con la de Montserrat-, al Sagrado Corazón -en 1919 y durante toda la dictadura - o al papa - con su visita en 1923 o con la emisión de los sellos de 1929-. El soberano español se había constituido en todo un símbolo de primer orden para el nacionalcatolicismo español. Era un elemento necesario para el sostenimiento de la religión parejo a la nación. De esta manera, se podría aventurar que el ser monárquico implicaba, casi de manera inexorable, el ser católico y viceversa - salvando excepciones, claro está-. Así, en los años veinte, el trono español sirvió de punto de encuentro entre la religión y la nación, constituyendo una suerte de trinidad que se convertiría en la esencia de la patria. Monarquía, catolicismo y nación eran tres entes necesariamente unidos e ineludibles para la

116 Para el concepto de «monarquizar la nación» véase Villares 2016.

117 Pemán 1929, 289 y 320.

118 La Parra López 2014. conservación de España tal y como la imaginaba el nacionalcatolicismo de la época. Y Alfonso XIII era la principal exteriorización y garantía de dicha concepción católica de nación.

\section{BiBLIOgRAFíA}

Adagio, Carmelo. 2004. Chiesa e nazione in Spagna. La dittadura di Primo de Rivera (1923-1930). Milano: Unicopli.

Alonso, Gregorio. 2015. «Imaginando a Fernando VII, rey católico y felón». Pasado y Memoria 14: 57-77.

Álvarez Junco, José. 2001. Mater dolorosa: la idea de España en el siglo $X I X$. Madrid: Taurus.

Arnstein, Walter. 1996. "Queen Victoria and the challenge of Roman Catholicism». The Historian 58: 295-314.

Barral Martínez, Margarita, coord. 2016. Alfonso XIII visita España: monarquía y nación. Granada: Comares.

Ben-Ami, Shlomo. 1983. La dictadura de Primo de Rivera. Barcelona: Planeta.

Billig, Michael. 2014. Nacionalismo banal. Madrid: Capitán Swing.

Botti, Alfonso. 1992. Cielo y dinero: el nacionalcatolicismo en España (1871-1975). Madrid: Alianza.

Botti, Alfonso. 2004. "La Chiesa di fronte a un regime autoritario. La dittadura di Primo de Rivera come 'occasione perduta'». En Cattolicesimo e totalitarismo. Chiese e cultura religiose tra le due guerra mondiali (Italia, Spagna, Francia), ed. Daniele Menozzi y Renato Moro, 75-123. Brescia: Morcelliana,

Botti, Alfonso. 2005. "Algo más sobre el nacionalcatolicismo». En Clericalismo y asociacionismo católico en España: de la Restauración a la Transición. Un siglo entre el palio y el consiliario, coord. Julio de la Cueva Merino y Ángel Luis López Villaverde, 195211. Cuenca: Ediciones de la Universidad de Castilla-La Mancha.

Botti, Alfonso. 2013. "Iglesia y nación en los años de entreguerras en la historiografía del postfranquismo». En Católicos y patriotas. Religión y nación en la Europa de entreguerras, ed. Alfonso Botti, Feliciano Montero y Alejandro Quiroga, 111-139. Madrid: Sílex.

Botti, Alfonso, Feliciano Montero y Alejandro Quiroga, eds. 2013. Católicos y patriotas. Religión y nación en la Europa de entreguerras. Madrid: Sílex.

Burdiel, Isabel. 2010. Isabel II. Una biografía (1830-1904). Madrid: Taurus.

Callahan, William James. 2003. La Iglesia católica en España (18752002). Barcelona: Crítica.

Cannadine, David. 2002. "Contexto, representación y significado del ritual: la monarquía británica y la 'invención de la tradición', c. 1820-1977». En La invención de la tradición, ed. Eric Hobsbawm y Terence O Ranger, 107-171. Barcelona: Crítica.

Cano, Luis. 2006. "Acerca de Cristo Rey». En Católicos entre dos guerras. Historia religiosa de España en los años 20 y 30, ed. Jaume Aurell y Pablo Pérez López, 173-201. Madrid: Biblioteca Nueva.

Cano, Luis. 2007. La devoción al Sagrado Corazón y a Cristo Rey en España y su recepción por los metropolitanos españoles (19231930). Roma: Tesis doctoral, Pontificia Universitas Sanctæ Crucis.

Cárcel Ortí, Vicente. 1988. «Iglesia y Estado durante la dictadura de Primo de Rivera (1923-1930)». Revista Española de Derecho Canónico 45: 209-248.

Cárcel Ortí, Vicente. 2009. "Pio XI e Alfonso XIII, re di Spagna». En La papauté contemporaine (XIXe-XXe siécles): hommage au chanoine Roger Aubert, professeur émérite à I'Université catholiqué de Louvain, pour ses 95 ans, 377-393. Ciudad del Vaticano: Archivio Segreto Vaticano.

Cárcel Ortí, Vicente. 2010. "Los últimos obispos de la Monarquía (1922-1931). Primera parte: Cuestiones generales y nombramientos conflictivos». Analecta Sacra Tarraconensia 83: 31-484.

Cárcel Ortí, Vicente. 2011a. «La Rota española y el Directorio militar. Conflictos diplomáticos con la Santa Sede entre 1924 y 1930». Revista Española de Derecho Canónico 68: 691-723. 
Cárcel Ortí, Vicente. 2011b. «Los últimos obispos de la monarquía (1922-1931). Segunda parte: Provisiones normales de diócesis». Analecta Sacra Tarraconensia 84: 223-734.

Christian, William A. y Zotán Krasnai. 2002-2003. «El Cristo de Limpias y la pasión de Hungría». Publicaciones del Instituto de Etnografía y folklore Hoyos Sainz 16: 113-140.

Colombo, Paolo. 2010. La monarchia fascista. 1922-1940. Bologna: II Mulino.

De la Cueva Merino, Julio. 2000. «Católicos en la calle: la movilización de los católicos españoles, 1898-1923». Historia y política 3: 55-80.

De la Cueva Merino, Julio. 2003. «El rey católico». En Alfonso XIII. Un político en el trono, ed. Javier Moreno Luzón, 277-306. Madrid: Marcial Pons.

De la Cueva Merino, Julio y Ángel Luis López Villaverde, coords. 2005. Clericalismo y asociacionismo católico en España: de la Restauración a la Transición. Un siglo entre el palio y el consiliario. Cuenca: Ediciones de la Universidad de Castilla-La Mancha.

Fernández Sirvent, Rafael y Rosa Ana Gutiérrez Lloret. 2014. «Discursos de legitimación de la monarquía española del siglo XIX: Isabel II y Alfonso XII, reyes constitucionales y católicos». Alcores 17: 89-114.

Gentile, Emilio. 2004. Fascismo. Historia e interpretación. Madrid: Alianza Editorial.

Gómez-Navarro, José Luis. 1991. El régimen de Primo de Rivera: reyes, dictaduras y dictadores. Madrid: Cátedra.

Gómez-Navarro, José Luis. 2003, «El rey en la dictadura». En Alfonso XIII, un político en el trono, ed. Javier Moreno Luzón, 337-372. Madrid: Marcial Pons.

González Cuevas, Pedro Carlos. 2003. «El rey y la corte». En Alfonso XIII. Un político en el trono, ed. Javier Moreno Luzón, 187-212. Madrid: Marcial Pons.

Gutiérrez-Ravé, José. 1955. Habla el rey. Discursos de don Alfonso XIII. Madrid: Industrias Gráficas.

Hernández Barral, José Miguel. 2012. Grandes de España: distin ción y cambio social, 1914-1931. Tesis doctoral. Universidad Complutense de Madrid.

Hernández Fuertes, Miguel Ángel. 2016. «La historia religiosa contemporánea en España: memoria, identidad y propuestas». Revista Expediçoes 7: 161-184.

Jedin, Hubert y Repgen, Konrad. 1984. Manual de Historia de la Iglesia: Tomo IX de La Iglesia mundial del siglo XX. Barcelona: Editoria Herder.

Lario, Ángeles. 1998. "La Corona en el Estado Liberal. Monarquía y constitución en la España del XIX». Historia Contemporánea 17: 139-157.

Lario, Ángeles. 1999. El Rey, piloto sin brújula. La Corona y el sistema político de la Restauración (1875-1902). Madrid: Biblioteca Nueva.

Lario, Ángeles. 2003. «Alfonso XII. El rey que quiso ser constitucional». Ayer 52: 15-38.

Lario, Ángeles, ed. 2017. «Un lugar para el rey: Conceptos, imágenes y atribuciones de la monarquía en el siglo XIX». Alcores 21.

La Parra López, Emilio. 2004. "La reina y la Iglesia». En Isabel II. Los espejos de la reina, ed. Juan Sisinio Pérez Garzón, 197-212. Madrid: Marcial Pons.

La Parra López, Emilio. 2014. «Fernando VII, el rey providencial enviado de Dios». Alcores 17: 39-53.

La Parra López, Emilio. 2015. «Hacia el fin de la monarquía del Antiguo Régimen». En Los viajes de la Razón: Estudios dieciochistas en homenaje a María-Dolores Albiac Blanco, coord. María Dolores Gimeno Puyol y Ernesto Viamonte Lucientes, 167-181. Zaragoza: Institución Fernando el Católico.

López Arana, Manuel. 1927. Sermón predicado en la S. I. C. de Santander con motivo del XXV aniversario de la coronación de Su Majestad el Rey D. Alfonso XIII (q. D. g) el día 17 de mayo de 1927 por el M. I. Sr. Dr. Don Manuel López Arana, Provisor del Obispado y Canónigo Doctoral. Santander: Ayuntamiento de Santander.

Louzao Villar, Joseba. 2013a. «Nación y catolicismo en la España contemporánea. Revisitando una interrelación histórica». Ayer 90: 65-89.

Louzao Villar, Joseba. 2013b. «La España mariana: vírgenes y nación en el caso español hasta 1939». En 'España res publica': nacionalización española e identidades en conflicto (siglos XIX y $X X)$, ed. Pere Gabriel Sirvent, Jordi Pomés i Vives y Francisco Fernández Gómez, 57-66. Granada: Comares.

Louzao Villar, Joseba. 2015. «Las imágenes de lo sagrado o cómo ser católico entre cambios y continuidades (c. 1875-1931)». Historia Contemporánea 51: 455-485.

María Muñoz, Guillermo. 2016. «Viaje historiográfico por la figura política de Alfonso XIII». Historiografías 12: 87-112.

Martínez Álvarez, Josefina. 2015. «Un paréntesis 'apacible’: las relaciones bilaterales entre España y el Vaticano durante la dictadura de Primo de Rivera». Aportes 88: 79-114.

Martínez Sánchez, Santiago y Miguel Ángel Dionisio Vivas. 2013. «Alma, púrpura y nación. Los cardenales Segura y Gomá ante la Historia de España». En Católicos y patriotas. Religión y nación en la Europa de entreguerras, ed. Alfonso Botti, Feliciano Montero y Alejandro Quiroga, 193-218. Madrid: Sílex.

Molina y Nieto, Ramón. 1928. En el solar de la piedad española: Crónica de la coronación de la Virgen de Guadalupe. Toledo: Imprenta y Encuadernación de J. Torres.

Montero, Feliciano. 2017. El movimiento católico en España, 18891936. Alcalá: Universidad de Alcalá Servicio de Publicaciones D. L.

Montero, Feliciano, Julio de la Cueva y Joseba Louzao, ed. 2017. La historia religiosa de la España contemporánea. Balance y perspectivas. Alcalá de Henares: Universidad de Alcalá Servicio de Publicaciones D.L.

Moreno Luzón, Javier, ed. 2003. Alfonso XIII. Un político en el trono. Madrid: Marcial Pons.

Moreno Luzón, Javier. 2013. «Alfonso 'el Regenerador'. Monarquía escénica e imaginario nacionalista español, en perspectiva comparada (1902-1913)». Hispania 244: 319-348. https://doi. org/10.3989/hispania.2013.009

Navajas Zubeldía, Carlos. 1991. Ejército, Estado y Sociedad en España (1923-1930). Logroño: Instituto de Estudios Riojanos.

Núñez Bargueño, Natalia. 2017. «'La reconquista de nuestro territorio cristiano': espacio urbano y religión en el Congreso Eucarístico Internacional de Madrid, 1911». Seminario de Historia Instituto Ortega y Gasset Documento de trabajo 2017/10, curso 2017/2018.

Olechnowicz, Andrzej, ed. 2007. The Monarchy and the British Nation, 1780 to the present. Cambridge: Cambridge University Press.

Ostolaza, Maitane. 2017. «La historiografía sobre las congregaciones religiosas y la educación en la España contemporánea (20002015). Balance y perspectivas». En La historia religiosa de la España contemporánea, Feliciano Montero, Julio de la Cueva y Joseba Louzao, 223-235. Alcalá de Henares: Universidad de Alcalá Servicio de Publicaciones D.L.

Pérez Garzón, Juan Sisinio, ed. 2004. Isabel II. Los espejos de la reina. Madrid: Marcial Pons.

Pemán, José María. 1929. El hecho y la idea de la Unión Patriótica. Madrid: Imprenta Artística Sáez Hermanos.

Perfecto García, Miguel Ángel. 1984. «Corporativismo y catolicismo social en la Dictadura de primo de Rivera». Studia historica 2: 123-147.

Peters, Diane. 1998. "A Celebration Of Empire, Queen Victoria's Diamond Jubilee». Caml Review 26, 2: 25-29.

Petrie, Charles. 1963. La monarquía inglesa contemporánea. Madrid: Cid.

Quiroga Fernández de Soto, Alejandro. 2008. Haciendo españoles: La nacionalización de las masas en la Dictadura de Primo de Rivera (1923-1930). Madrid: Centro de Estudios Políticos y Constitucionales.

Quiroga Fernández de Soto, Alejandro. 2013. «La trampa católica. La iglesia y la dictadura de Primo de Rivera». En Católicos y patriotas. Religión y nación en la Europa de entreguerras, ed. Alfonso Botti, Feliciano. Montero y Alejandro Quiroga, 161-191. Madrid: Sílex.

Ramón Solans, Francisco Javier. 2014. «Un templo para la nación, la Basílica del Pilar (1854-1940)». Hispania Sacra 66, extra I: 453-484. https://doi.org/10.3989/hs.2014.082

Ramón Solans, Francisco Javier. 2015. “'El catolicismo tiene masas'. Nación, política y movilización en España, 1868-1931». Historia Contemporánea 51: 427-454. 
Regatillo, Eduardo. F. 1927. Espejo de Reyes. Santander: Talleres Tipográficos J. Martínez.

Rodríguez Lago, José Ramón. 2012. «La batalla eclesial por Madrid (1923-1936) Los conflictos entre Eijo Garay y Federico Tedeschini». Hispania Sacra LXIV, extra I: 205-222. https://doi.org/10.3989/ hs. 2012.030

Rodríguez Lago, José Ramón. 2017. «Las claves de Tedeschini. La política Vaticana en España (1921-1936)». Historia y política 38: 229258. https://doi.org/10.18042/hp.38.08

Rodríguez López, Ana. 1991. «Fernando III el Santo (1217-1252): evolución historiográfica, canonización y utilización política». En Miscel/lània en homenatge al P. Agustí Altisent, 573-588. Tarragona: Diputación de Tarragona.

Rubio Cabeza, Manuel. 1986. Crónica de la Dictadura de Primo de Rivera. Madrid: Sarpe.

Salomón Chéliz, María Pilar. 2015. «Entre el insurrecionalismo y e posibilismo: las culturas políticas del catolicismo español (18751936)». En La Restauración y la República. 1874-1936, coord. Carlos Forcadell y Manuel Suárez Cortina, 315-344. Madrid: Marcial Pons - Prensa de la Universidad de Zaragoza.

Seco Serrano, Carlos. 1986. «El cerco de la monarquía. La ruptura de los partidos dinásticos con Alfonso XIII durante la dictadura de Primo de Rivera». Boletín de la Real Academia de la Historia CLXXXIII, cuaderno II: 161-269.

Soldevilla, Ferran. 1924. El año político. 1923. Madrid: Imprenta de Julio Costano.

Suárez Cortina, Manuel. 2015. «Catolicismo y nación. 1875-1936». En La Restauración y la República. 1874-1936, coord. Carlos Forcadel y Manuel Suárez Cortina, 27-54. Madrid: Marcial Pons - Prensa de la Universidad de Zaragoza.

Tusell, Javier. 1993. «El rey y el Dictador». Espacio, Tiempo y Forma 6: 15-32.
Tusell, Javier. 1997. "La Dictadura de Primo de Rivera (1923-1930)». En Del Plano inclinado hacia la dictadura al final de la monarquía. 1922-1931, Javier Tusell y Carlos Seco Serrano, 133-623. Tomo XXXVIII, vol. II, de Historia de España Menéndez Pidal. Madrid: Espasa Calpe.

Unowsky, Daniel. 1998. "Creating Patriotism. Imperial Celebrations and the Cult of Franz Joseph». Österreichische Zeitheschichte 9: 280-293.

Varela, Benigno. 1925. El rey D. Alfonso XIII ante S. S. Pío XI. Una fecha histórica para el catolicismo mundial. Madrid: Editorial La Monarquía.

Vegas Latapié, Eugenio. 1983. Memorias políticas. El suicidio de la Monarquía y la Segunda República. Barcelona: Planeta.

Villacampa, Carlos G. 1928. Alfonso XI, "el del Salado», Alfonso XII, "el Pacificador» y Alfonso XIII, "el Católico»: relaciones de estos gloriosísimos monarcas españoles con el Santuario / discurso pronunciado por Carlos G. Villacampa... en la vela-da celebrada en el Monasterio, en honor de Su Majestad el rey Don Alfonso XIII, el día 11 de octubre de 1928, con motivo de la coronación de la Virgen de Guadalupe. Cáceres: Tipografía Extremadura.

Villares, Ramón. 2016. «Prólogo». En Alfonso XIII visita España: monarquía y nación, coord. Margarita Barral Martínez, XI-XVIII. Granada: Comares.

Vincent, Mary. 2013. «Religión e identidad nacional». En Ser españoles. Imaginarios nacionalistas en el siglo $X X$, ed. Javier Moreno Luzón y Xosé M. Núñez Seixas, 207-245. Barcelona: RBA.

Wolf, Christiane. 2010. «¿Los monarcas como representantes religiosos de la nación hacia 1900? Una comparación entre el káiser Guillermo II, la reina Victoria y el emperador Francisco José». En Nación y religión en Europa. Sociedades multiconfesionales en los siglos XIX y XX, ed. Heinz-Gerhard Haupt y Dieter Langewiesche, 177-198. Zaragoza: Institución Fernando el Católico (CSIC). 